\title{
Present status of implementation of undergraduate curriculum of Bangladesh in selected private medical colleges: Teachers perspectives
}

\author{
Abu Syed Md. Mosaddek, Md. Zakirul Islam², Md. Faizur Rahman ${ }^{3}$, Habib S. Chaudhury", \\ Roksana Parvin ${ }^{5}$, Matira Khanom ${ }^{6}$
}

\begin{abstract}
'Associate Professor, Department of Pharmacology, Uttara Adhunik Medical College, Uttara, Dhaka; ${ }^{2}$ Assistant Professor, Department of Pharmacology, Eastern Medical College, Comilla; ${ }^{3}$ Assistant Professor, Department of Pharmacology, Kumudini Medical College, Tangail; ${ }^{4}$ Associate Professor, Department of Biochemistry, International Medical College, Gazipur; ${ }^{5}$ Assistant Professor, Department of Pharmacology, Medical College for Women and Hospital, Uttara, Dhaka; ${ }^{6}$ Assistant Professor, Department of Pharmacology, Ibn Sina Medical college and Hospital, Kallanpur, Dhaka, Bangladesh.
\end{abstract}

\section{To the Editor}

In recent years, medical education in developed and developing countries has undergone profound changes to keep pace with advancing public health needs and challenges. ${ }^{1}$ To reorient medical education in the South-East Asian Region, the adoption of the World Federation for Medical Education (WFME) Global Standards in Medical Education was emphasized. ${ }^{2}$ A significant number of reports by national ${ }^{3,4}$ and international organizations ${ }^{5-7}$ also suggested strategies for direction to such changes. In Bangladesh, a community-oriented and competency-based undergraduate medical curriculum was implemented in 2002 with an aim to produce need-based doctors for the community. ${ }^{8,9}$ However, it was felt necessary that there should be an ongoing evaluation of the curriculum to make it more responsive to community health needs. ${ }^{8-10}$ This study was designed to investigate the opinions of medical teachers on the present status of implementation of undergraduate curriculum of Bangladesh in selected private medical colleges.

A cross-sectional, questionnaire-based study involving medical teachers was conducted at six private medical colleges* of Bangladesh during the period of June-July 2011. The questionnaire included questions on different aspects of implementation of undergraduate curriculum in the private medical colleges. The teachers were selected purposively. The questionnaire was distributed among 80 teachers and was returned by 60 teachers. There were 37 male and 23 female respondents; 20 assistant professors, 25 associate professors and 15 professors; and the mean length of the teaching experience of the respondents was 15 years. Teachers' views on the present status of the implementation of the undergraduate medical curriculum are shown in detail in Table 1. About $68 \%$ were dissatisfied with present status of implementation of undergraduate curriculum and they recommended a review of the curriculum to include more community-oriented and competency-based elements in teaching-learning approaches. Though $80 \%$ of the teachers were satisfied with course contents, more than $40 \%$ have disclosed their dissatisfaction with the course timing. Most of the teachers (85\%) were not in favor of present 'Carry On' system. Premedical education was not recommended by majority of respondents (78\%); however they supported teaching and training on the English language and professionalism during this period. The majority of the teachers were pleased with the present system of admission tests $(75 \%)$ and internship training $(70 \%)$. Most of the teachers also showed their satisfaction with the current assessment system: written $(80 \%)$, oral (55\%), and practical (75\%). However, some concerns were raised by teachers and provided specific suggestions for MCQs (e.g. introduction of negative markings, increased number of questions, consideration of difficulty index in MCQs), oral examinations (setting topic-based questions, questions supplied by university or a central committee, number of examinees should be limited to 10 students per day, and maintain similar standards in all medical colleges) and practical examinations (setting standards, and should be practical and clinical oriented).

A few teachers gave the opinion to exclude community medicine from phase one. Teachers, who complained about shorter time duration in this phase, suggested that first professional examination should be completed within second year of the course as frequent examination schedules are time consuming which puts students in tremendous stress. In the second phase, teachers are satisfied with two years duration for five subjects (pharmacology \& therapeutics, microbiology, pathology, community medicine and forensic medicine) but raised concern regarding second professional examination with these five subjects at a time which they thought as is a burden for the students.

Correspondence: Dr. Abu Syed Md. Mosaddek, Department of Pharmacology, Uttara Adhunik Medical College, Uttara, Dhaka, Bangladesh.E-mail:Drmosaddek@yahoo.ca. 
Table 1: Teachers' views on present status of implementation of undergraduate medical curriculum

\begin{tabular}{|c|c|c|}
\hline Topics & Yes $(\%)$ & No $(\%)$ \\
\hline $\begin{array}{l}\text { Satisfied with the present } \\
\text { status of implementation }\end{array}$ & $19(31.6 \%)$ & $41(68.4 \%)$ \\
\hline $\begin{array}{l}\text { Satisfied with course } \\
\text { contents }\end{array}$ & $48(80 \%)$ & $12(20 \%)$ \\
\hline $\begin{array}{l}\text { Requirement of carry on } \\
\text { system }\end{array}$ & $9(15 \%)$ & $51(85 \%)$ \\
\hline $\begin{array}{l}\text { Requirement of pre- } \\
\text { medical education }\end{array}$ & $13(21.7 \%)$ & $47(78.3 \%)$ \\
\hline $\begin{array}{l}\text { Difficulty in respective } \\
\text { phase as a whole }\end{array}$ & $27(45 \%)$ & $33(55 \%)$ \\
\hline $\begin{array}{l}\text { Difficulty in respective } \\
\text { subject }\end{array}$ & $28(46.7 \%)$ & $32(53.3 \%)$ \\
\hline $\begin{array}{l}\text { Satisfied with the present } \\
\text { system of admission tests }\end{array}$ & $45(75 \%)$ & $15(25 \%)$ \\
\hline $\begin{array}{l}\text { Satisfied with internship } \\
\text { training }\end{array}$ & $42(70 \%)$ & $18(30 \%)$ \\
\hline $\begin{array}{l}\text { Regarding dividing second } \\
\text { professional examination } \\
\text { in two parts }\end{array}$ & $57(95 \%)$ & $3(5 \%)$ \\
\hline $\begin{array}{l}\text { Satisfaction with written } \\
\text { part of assessment }\end{array}$ & $48(80 \%)$ & $12(20 \%)$ \\
\hline $\begin{array}{l}\text { Satisfaction with oral part } \\
\text { of assessment }\end{array}$ & $33(55 \%)$ & $27(45 \%)$ \\
\hline $\begin{array}{l}\text { Satisfaction with practical } \\
\text { part of assessment }\end{array}$ & $45(75 \%)$ & $15(25 \%)$ \\
\hline
\end{tabular}

Majority of the teachers $(95 \%)$ recommended dividing this professional examination into two parts. In the third phase, teachers are satisfied with course contents, duration and final professional examination. Teachers of second and third phases were in favor of reorganization of curriculum and suggested better co-ordination and adjustment of paraclinical examinations, day-visits and clinical placements.

Curriculum planning and designing is not a static process, rather a continuous process done regularly through a formal system. More than one decade has elapsed since the undergraduate medical curriculum in Bangladesh was developed and implemented, however, until now, full-scale evaluation involving all stake-holders has not been undertaken to update the curriculum. ${ }^{8-10}$ This was reflected in this study as majority of the teachers have expressed their dissatisfaction with the present status of the implementation of the curriculum both in public and private medical colleges. The concerns regarding short duration of phase one, decreasing academic contact hours, students' stress, carry on system, assessment system and English language training need careful consideration. There should be an effective monitoring and evaluation system to review the curriculum on an ongoing basis. For this, the organizational and operational structure of Quality Assurance System ${ }^{11}$ and independent, external, effective, transparent system of accreditation and quality assurance mechanisms ${ }^{2,11}$ should be fully implemented in all medical colleges, both private and public. ${ }^{11}$ Bangladesh Medical and Dental Council and Centre for Medical Education should play pivotal roles in this regard. Students, teachers, external examiners, ex-students, physicians and others stakeholders' views should be sought formally to review the curriculum on a continuous basis.

* Medical colleges were Uttara Adhunik Medical College, Dhaka; International Medical College, Gazipur; Medical College for Women and Hospital, Dhaka; Eastern Medical College, Comilla; Kumudini Medical College, Tangail; and Ibn Sina Medical College and Hospital, Dhaka, Bangladesh.

\section{References}

1. Majumder MAA, D'Souza U, Rahman S. Trends in Medical Education: challenges and directions for needbased reforms of medical training in south-east Asia. Indian JMed Sci. 2004; 58:369-80.

2. Karle H. Relevance of the WFME Global Standards in Medical Education in the South East Asian Region. South East Asian JMed Educ 2007; 1:2-7.

3. Stewart A. Report on a Consultancy for Quality Assurance in Medical Education, Dhaka, August 1997. Dhaka: FIMC Project; 1997.

4. Bryce CFA. Report on a Consultancy for Quality Assessment and Audit Review (QAAR) in Medical Education, Dhaka, Rangpur and Chittagong. Dhaka: FIMC Project; 1998.

5. General Medical Council. Tomorrow's Doctors. Outcomes and standards for undergraduate medical education, London: General Medical Council, 2009.

6. World Federation for Medical Education. Recommendations of World Summit on Medical Education, Aug 8-12 1993, Edinburgh. Med Educ 1994; 28:142-9.

7. WHO. Community-based education of health personnel: Report of a WHO study group. Geneva: World Health Organization; 1987.

8. Amin Z, Merrylees N, Hanif A, Talukder MH. Medical education in Bangladesh. Med Teach 2008;30:243-7.

9. Majumder MAA. A review of the undergraduate medical curriculum in Bangladesh. Bangladesh Med J 2002;31:47-9.

10. Majumder MAA. Medical Education in Bangladesh: Past Successes, Future Challenges. Bangladesh Med J 2003;32:37-9.

11. Further Improvement of Medical College Project. Quality Assurance Handbook. Dhaka: FIMC Project; 1998. 